\title{
ANALISIS CAMEL UNTUK MENILAI TINGKAT KESEHATAN PT. BANK MESTIKA DHARMA, TBK
}

\author{
Oleh: \\ Wenly Roedily \\ S1 Akuntansi \\ Parman Tarigan, Mahaitin Sinaga, Rosanna Purba
}

\begin{abstract}
Abstraksi
Tujuan dari penelitian ini yaitu untuk menilai tingkat kesehatan PT. Bank Mestika Dharma, Tbk pada periode kuartal kedua tahun 2011 (Juni 2011) sampai dengan kuartal kedua tahun 2013 (Juni 2013). Teknik analisa data yang digunakan dalam penelitian ini adalah analisis CAMEL yang meliputi aspek Capital, Asset, Management, Earning dan Liquidity. CAMEL merupakan alat untuk menganalisis keuangan suatu bank dan untuk penilaian manajemen bank yang ditetapkan oleh Bank Indonesia untuk mengetahui tingkat kesehatan bank melalui aspek - aspek tersebut.

Hasil dari analisis CAMEL menunjukkan bahwa tingkat kesehatan PT. Bank Mestika Dharma, Tbk secara keseluruhan pada periode Juni 2011 sampai dengan Juni 2013 berada di predikat Sehat. Adapun aspek Capital yang dimiliki oleh PT. Bank Mestika Dharma, Tbk dikategorikan dalam kelompok Sehat. Untuk aspek Assets yang dimiliki oleh PT. Bank Mestika Dharma, Tbk juga dikategorikan dalam kelompok Sehat. Kemudian untuk aspek Management yang diproyeksikan dengan menggunakan rasio Net Profit Margin dikategorikan dalam kelompok SEHAT. Berikutnya untuk aspek Earning yang dicapai oleh PT Bank Mestika Dharma, Tbk juga dikategorikan dalam kelompok Sehat. Aspek Liquidity PT. Bank Mestika Dharma, Tbk juga berada di predikat Sehat.
\end{abstract}

Kata Kunci : Analisis CAMEL, Tingkat Kesehatan Bank

\section{Abstraction}

Intention of this research that is to assess the level of health PT. Bank of Mestika Dharma, Tbk at second period semester of year 2011 (June 2011) up to second semester of year 2013 (June 2013). Technique analyze the data used in this research is analysis CAMEL covering aspect Capital, Asset, Management, Earning and Liquidity. CAMEL represent the appliance for the financial analysis of bank and for the assessment of bank management specified by Indonesia Bank to know the level of bank health of through aspect - the aspect.

Result from analysis CAMEL indicate that the level of health PT. Bank of Mestika Dharma, Tbk as a whole at June period 2011 up to June 2013 residing in Healthy predicate. As for aspect Capital owned by PT. Bank of Mestika Dharma, Tbk categorized in Healthy group. For the aspect of Assets owned by PT. Bank of Mestika Dharma, Tbk is also categorized in Healthy group. Then for the aspect of Management which projected by using ratio of Net Profit Margin categorized in Healthy group. for the aspect of reached Earning by PT of Bank of Mestika Dharma, Tbk is also categorized in Healthy group. Aspect of Liquidity PT. Bank of Mestika Dharma, Tbk also reside in the Healthy predicate.

Keyword: Analyze The CAMEL, Mount the Bank Health

\section{A. PENDAhUluAN}

\section{Latar Belakang Masalah}

Perkembangan metodologi penilaian kondisi keuangan bank senantiasa bersifat dinamis sehingga sistem penilaian tingkat kesehatan keuangan bank terus disesuaikan agar lebih mencerminkan kondisi bank saat ini dan di waktu yang akan datang. Tingkat kesehatan keuangan bank adalah hasil penilaian kualitatif atas berbagai aspek yang berpengaruh terhadap kondisi atau kinerja suatu bank melalui Penilaian Kuantitatif dan atau Penilaian Kualitatif terhadap faktor - faktor Capital, Asset Quality, Management, Earning, dan Liquidity yang disingkat CAMEL.

Menghadapi persaingan di sektor perbankan yang semakin ketat, kepercayaan dari masyarakat merupakan salah satu kunci sukses yang mendorong kemajuan perusahaan. Beranjak dari hal tersebut maka PT. Bank Mestika Dharma, Tbk secara berkesinambungan terus melakukan evaluasi dan perbaikan terutama di bidang pelayanan, pengembangan produk, fungsi pemasaran serta pengembangan jaringan kantor, agar mampu mewujudkan visi sebagai bank terpercaya, menjadi kebanggaan masyarakat serta mampu menunjang pembangunan daerah. Mengingat fungsi, posisi dan peranan PT. Bank Mestika Dharma, Tbk di tengah tengah masyarakat yang begitu strategis, maka kepentingan akan pengukuran tingkat kesehatannya menjadi begitu penting agar dikemudian hari PT. Bank Mestika Dharma, Tbk lebih dapat diterima oleh masyarakat dan tetap dipercaya oleh kalangan pemerintah maupun swasta dalam pengelolaan keuangan bisnisnya. 


\section{Rumusan Masalah}

Dengan dasar pemikiran di atas, maka dapat diidentifikasikan rumusan masalah, yaitu sebagai berikut: bagaimanakah tingkat kesehatan PT. Bank Mestika Dharma jika dinilai dengan analisis CAMEL?

\section{Tujuan Penelitian}

Adapun tujuan dari penelitian ini adalah untuk mengetahui tingkat kesehatan PT. Bank Mestika Dharma, Tbk jika dinilai dengan analisis CAMEL.

\section{Metode Penelitian}

Desain penelitian merupakan suatu cara yang sistematis dan objektif dengan maksud untuk memperoleh data atau mengumpulkan keterangan untuk diteliti. Adapun Desain penelitian yang digunakan adalah Penelitian Kepustakaan (Library Research) dan Penelitian Lapangan (Field Research).

Pada penelitian ini, penilaian terhadap aspek Capital (Kecukupan Modal) menggunakan rasio CAR (Capital Adequacy Ratio) yaitu perbandingan antara rasio modal terhadap aktiva tertimbang menurut resiko (ATMR). Aspek Assets (Kualitas Aset Produktif) diukur dengan menggunakan rasio Kualitas Aset Produktif (KAP) dan rasio Penyisihan Penghapusan Aset Produktif (PPAP). Untuk aspek Management (Kualitas Manajemen) pada penelitian ini diproksikan dengan menggunakan rasio Net Profit Margin (NPM). Sedangkan untuk aspek Earnings (Kemampuan Menghasilkan Laba) menggunakan dua rasio, yaitu Return On Asset (ROA) dan Biaya Operasional terhadap Pendapatan Operasional (BOPO). Aspek Liquidity (Kemampuan Menjamin) diukur dengan menggunakan dua rasio, yaitu Cash Ratio (CR) dan Loan To Deposit Ratio (LDR).

\section{B. LANDASAN TEORI}

\section{Laporan Keuangan}

Menurut Kasmir (2011:253), setiap perusahaan, baik bank maupun non bank pada suatu waktu (periode tertentu) akan melaporkan semua kegiatan keuangannya. Menurut Dendawijaya (2009:109), laporan perhitungan laba rugi atau lebih dikenal juga dengan income statement dari suatu bank umum adalah suatu laporan keuangan bank yang menggambarkan pendapatan dan biaya operasional dan non operasional bank untuk suatu periode tertentu.

Berdasarkan PSAK nomor 1 revisi 2009 Penyajian Laporan Keuangan, unsur laporan keuangan yang berkaitan secara langsung dengan pengukuran posisi keuangan adalah aset, kewajiban dan ekuitas. Menurut Kasmir (2011:257), dalam praktiknya, jenis - jenis laporan keuangan bank adalah sebagai berikut :

a. Neraca: merupakan laporan yang menunjukkan posisi keuangan bank pada tanggal tertentu. Posisi keuangan dimaksudkan adalah posisi aset, liabilitas, dan ekuitas suatu bank. Penyususnan komponen di dalam neraca didasarkan pada tingkat likuiditas dan jatuh tempo.

b. Laporan Komitmen dan Kontinjensi: merupakan suatu ikatan atau kontrak yang berupa janji yang tidak dapat dibatalkan secara sepihak (irrevocable) dan harus dilaksanakan apabila persyaratan yang disepakati bersama dipenuhi. Contoh laporan komitmen adalah komitmen kredit, komitmen penjualan atau pembelian aset bank dengan syarat Repurchase Agreement (Repo), sedangkan laporan kontinjensi merupakan tagihan atau kewajiban bank yang kemungkinan timbulnya tergantung pada terjadi atau tidak terjadinya satu atau lebih peristiwa di masa yang akan datang. Penyajian laporan komitmen dan kontinjensi disajikan tersendiri tanpa pos lama.

c. Laporan Laba Rugi: merupakan laporan keuangan bank yang menggambarkan hasil usaha bank dalam suatu periode tertentu. Dalam laporan ini tergambar jumlah pendapatan dan sumber - sumber pendapatan serta jumlah biaya dan jenis - jenis biaya yang dikeluarkan.

d. Laporan Arus Kas: merupakan laporan yang menunjukkan semua aspek yang berkaitan dengan kegiatan bank, baik yang berpengaruh langsung maupun tidak langsung terhadap kas. Laporan arus kas harus disusun berdasarkan konsep kas selama periode laporan.

e. Catatan atas Laporan Keuangan: merupakan laporan yang berisi catatan tersendiri mengenai Posisi Devisa Neto, menurut jenis mata uang dan aktivitas lainnya.

f. Laporan Keuangan Gabungan dan Konsolidasi: Laporan gabungan merupakan laporan dari seluruh cabang-cabang bank yang bersangkutan, baik yang ada di dalam negeri maupun di luar negeri, sedangkan laporan konsolidasi merupakan laporan bank yang bersangkutan dengan anak perusahaannya.

g. Laporan Keuangan Interim: berdasarkan PSAK No. 3 (Revisi 2010) tentang Laporan Keuangan Interim, laporan keuangan interim merupakan laporan keuangan yang berisi baik laporan keuangan lengkap atau laporan keuangan ringkas untuk suatu periode interim. Periode interim adalah suatu periode laporan keuangan yang lebih pendek dari satu tahun buku penuh.

\section{Kesehatan Bank}

Berdasarkan Pasal 29 UU No. 7 Tahun 1992 sebagaimana telah diubah dengan UU No. 10 Tahun 1998 tentang Perbankan, bank wajib memelihara tingkat kesehatannya sesuai dengan ketentuan kecukupan modal, kualitas aset, kualitas manajemen, likuiditas, rentabilitas dan solvabilitas, serta aspek lain yang berkaitan dengan usaha bank dan wajib melakukan kegiatan usaha sesuai dengan prinsip kehati-hatian.

Menurut Surat Edaran Bank Indonesia Nomor : 6/23/DPNP tanggal 31 Mei 2004, penilaian tingkat kesehatan bank merupakan penilaian kualitatif atas berbagai aspek yang berpengaruh 
terhadap kondisi atau kinerja suatu bank melalui penilaian aspek permodalan, kualitas aset, manajemen, rentabilitas, likuiditas dan sensitivitas terhadap resiko pasar. Penilaian terhadap faktorfaktor tersebut dilakukan melalui penilaian kuantitatif dan kualitatif setelah mempertimbangkan unsur judgement yang didasarkan atas meterialitas dan signifikansi dari faktor-faktor penilaian serta pengaruh dari faktor lainnya seperti kondisi industri perbankan dan perekonomian nasional.

Bagi perbankan, hasil akhir penilaian kondisi bank tersebut dapat digunakan sebagai salah satu sarana dalam menetapkan strategi usaha di waktu yang akan datang sedangkan bagi Bank Indonesia antara lain dapat digunakan sebagai sarana penetapan dan implementasi strategi pengawasan bank oleh Bank Indonesia.

Penggolongan tingkat kesehatan bank dibagi dalam empat kategori yaitu : sehat, cukup sehat, kurang sehat dan tidak sehat, namun sistem pemberian nilai dalam menetapkan tingkat kesehatan bank didasarkan pada "reward system" dengan nilai kredit antara 0 sampai dengan 100, di mana menurut ketentuan dari Bank Indonesia nilai kredit maksimum adalah 100. Apabila nilai kredit rasio CAMEL lebih dari itu maka nilai kredit rasio diakui sebagai 100. Nilai kredit penggolongan tingkat kesehatan bank diuraikan dalam tabel berikut:

Tabel 1

Nilai Kredit Penggolongan Tingkat Kesehatan Bank

\begin{tabular}{|c|c|}
\hline Nilai Kredit & Predikat \\
\hline $81-100$ & Sehat \\
\hline $66-<81$ & Cukup Sehat \\
\hline $51-<66$ & Kurang Sehat \\
\hline $0-<51$ & Tidak Sehat \\
\hline
\end{tabular}

Sumber: SE BI Nomor 6/23/DPNP tanggal 31 Mei 2004

Bank Indonesia sebagai pengawas dan pembina bank-bank dapat memberikan arahan atau petunjuk bagaimana bank tersebut harus dijalankan atau bahkan dihentikan kegiatan operasinya. Ukuran untuk melakukan penilaian kesehatan bank telah dibuat oleh Bank Indonesia. Sedangkan bank-bank diharuskan untuk membuat laporan baik bersifat rutin ataupun secara berkala mengenai seluruh aktivitasnya dalam suatu periode tertentu.

\section{Metode CAMEL}

Menurut Kasmir (2011:273), salah satu alat untuk mengukur kesehatan bank adalah dengan analisis CAMEL. Unsur-unsur penilaian dalam analisis CAMEL adalah sebagai berikut :

a. Capital: penilaian didasarkan kepada permodalan yang dimiliki oleh salah satu Bank. Salah satu penilaian adalah dengan metode CAR (Capital Adequacy Ratio) yaitu dengan cara membandingkan modal terhadap aset tertimbang menurut resiko (ATMR). Rasio CAR dapat dirumuskan sebagai berikut:

Rasio CAR $=($ Modal Bank $) /($ Aktiva Tertimbang Menurut Risiko) X $100 \%$

b. Assets: penilaian didasarkan kepada kualitas aset yang dimiliki Bank. Rasio yang diukur ada 2 macam yaitu: Rasio aset produktif yang diklasifikasikan terhadap aset produktif atau disebut juga Rasio Kualitas Aktiva Produktif (KAP), Rasio penyisihan penghapusan aset produktif terhadap aset produktif yang diklasifikasikan (PPAP) Kedua rasio di atas dapat dirumuskan sebagai berikut.

Rasio KAP = (Aktiva Produktif yang Diklasifikasikan)/(Jumlah Aktiva Produktif) X $100 \%$

dan

Rasio PPAP = PPAP/PPAPWD X $100 \%$

di mana PPAP adalah Penyisihan Penghapusan Aset Produktif dan PPAWD adalah Penyisihan Penghapusan Aset Produktif yang Wajib Dibentuk.

c. Management: penilaian didasarkan kepada manajemen permodalan, manajemen aset, manajemen rentabilitas, manajemen likuiditas dan manajemen umum. Manajemen bank dinilai atas dasar 250 pertanyaan yang diajukan. Akan tetapi pengukuran tersebut sulit dilakukan karena akan terkait dengan unsur kerahasiaan bank, maka dalam penelitian ini aspek manajemen diproksikan dengan profit margin dengan pertimbangan rasio ini menunjukkan bagaimana manajemen mengelola sumber-sumber maupun penggunaan atau alokasi dana secara efisien. Menurut Amalia (2012:26) Penggunaan Net Profit Margin (NPM) juga erat kaitannya dengan aspek-aspek manajemen yang dinilai, baik dalam manajemen umum maupun manajemen risiko, di mana net income dalam aspek manajemen umum mencerminkan pengukuran hasil dari strategi keputusan yang dijalankan dan dalam tekniknya dijabarkan dalam bentuk sistem pencatatan, pengamanan, dan pengawasan dari kegiatan operasional bank dalam upaya memperoleh operating income yang optimum. Sedangkan net income dalam manajemen risiko mencerminkan pengukuran terhadap upaya mengeliminir risiko likuiditas, risiko kredit, risiko operasional, risiko hukum, dan risiko pemilik dari kegiatan operasional bank, untuk memperoleh operating income yang optimum. Dapat juga dikatakan net profit margin mencerminkan tingkat efektifitas yang dapat dicapai oleh usaha operasional bank, yang terkait dengan hasil akhir dari berbagai kebijaksanaan dan keputusan yang telah dilaksanakan oleh bank dalam periode berjalan. Menurut Kasmir (2011:298) Net Profit Margin (NPM) dapat dirumuskan sebagai berikut.

Rasio NPM $=($ Net Income $) /($ Operation Income $)$ $\mathrm{X} 100 \%$

d. Earnings: penilaian didasarkan kepada rentabilitas suatu bank yaitu melihat kemampuan suatu bank dalam menciptakan laba. Penilaian dalam unsur ini didasarkan kepada 2 macam yaitu:

Rasio laba terhadap total aset (Return on Assets / ROA) dan Rasio beban operasional terhadap pendapatan operasional (BOPO). Adapun kedua rasio di atas dapat dirumuskan sebagai berikut. 
Rasio ROA = (Laba Sebelum Pajak $) /($ Total Aset $)$ $\mathrm{X} 100 \%$ dan

Rasio BOPO $=($ Beban Operasional $) /($ Pendapatan Operasional) X $100 \%$

Berdasarkan Lampiran 1d Surat Edaran Bank Indonesia No.6/23/DPNP tanggal 31 Mei 2004, untuk rasio ROA, perhitungan laba sebelum pajak disetahunkan. Contoh, untuk posisi Juni maka perhitungan laba sebelum pajak adalah akumulasi laba per posisi Juni dibagi 6, kemudian dikali 12 .

e. Liquidity: merupakan penilaian likuiditas bank, yaitu kemampuan bank dalam memenuhi kewajibannya setiap saat. Menurut Sudirman (2013:158) Penilaian likuiditas bank didasarkan kepada 2 macam rasio yaitu: Rasio alat likuid terhadap utang lancar (Liquid Assets to Current Liability Ratio / LACLR) atau disebut juga dengan Cash Ratio (CR). Rasio antara kredit terhadap dana yang diterima oleh bank (Loan to Deposit Ratio / LDR). Kedua rasio di atas dapat dirumuskan sebagai berikut.

Rasio $\mathrm{CR}=$ (Alat Likuid) $/($ Utang Lancar $) \mathrm{X}$ $100 \%$

dan

Rasio LDR $=$ Kredit/(Dana yang diterima oleh bank) X $100 \%$

Berdasarkan Surat Edaran Bank Indonesia Nomor 6/23/DPNP tanggal 31 Mei 2004, dalam rangka penerapan ketentuan yang memerlukan persyaratan tingkat kesehatan bank maka predikat tingkat kesehatan bank seperti yang terlihat pada tabel, diberi keterangan sebagai berikut:

untuk predikat Tingkat Kesehatan "Sehat" dipersamakan dengan Peringkat Komposit 1 (PK-1) atau Peringkat Komposit 2 (PK-2).

a. untuk predikat Tingkat Kesehatan "Cukup Sehat" dipersamakan dengan Peringkat Komposit 3 (PK-3)

b. untuk predikat Tingkat Kesehatan "Kurang Sehat" dipersamakan dengan Peringkat Komposit 4 (PK-4).

c. untuk predikat Tingkat Kesehatan "Tidak Sehat" dipersamakan dengan Peringkat Komposit 5 (PK-5).

\section{PEMBAHASAN}

\section{Analisa}

Berikut ini adalah analisis CAMEL terhadap Laporan Keuangan PT Bank Mestika Dharma, Tbk periode kuartal kedua tahun 2011 (Juni 2011) sampai dengan kuartal kedua tahun 2013 (Juni 2013) yang digunakan untuk menilai tingkat kesehatan PT. Bank Mestika Dharma, Tbk.

\section{a. Capital (Kecukupan Modal)}

Penilaian terhadap capital dihitung dengan metode rasio CAR (Capital Adequacy Rasio) yaitu dengan cara membandingkan modal terhadap aset tertimbang menurut resiko (ATMR). Berdasarkan hasil perhitungan rasio Capital Adequacy Ratio
(CAR) pada periode kuartal kedua 2011 sampai dengan kuartal kedua 2013, menunjukkan rasio CAR lebih besar dari kriteria penilaian tingkat kesehatan bank yang ditetapkan oleh Bank Indonesia sebesar $8 \%$, dengan rata - rata nilai kredit rasio CAR pada periode tersebut adalah sebesar 274,88 . Oleh karena nilai kredit rasio dibatasi maksimum 100 maka nilai kredit rasio CAR di atas diakui sebagai 100. Untuk aspek Capital yang diukur dengan rasio CAR maka PT. Bank Mestika Dharma, Tbk dikategorikan dalam kelompok Sehat.

\section{b. Assets (Kualitas Aset Produktif)}

Penilaian terhadap Assets dihitung dengan metode Kualitas Aset Produktif (KAP) dan Penyisihan Penghapusan Aset Produktif (PPAP). Adapun perhitungan rasio KAP dan rasio PPAP untuk periode kuartal kedua 2011 sampai dengan kuartal kedua 2013 menunjukkan rasio KAP yang dicapai PT. Bank Mestika Dharma, Tbk dikategorikan dalam kelompok SEHAT, di mana persentase rasio KAP semakin lama semakin kecil sehingga nilai kreditnya semakin besar melebihi nilai kredit maksimum yang ditetapkan oleh Bank Indonesia. Rata - rata nilai kredit rasio KAP adalah sebesar 130,30. Oleh karena nilai kredit rasio dibatasi maksimum 100 maka nilai kredit rasio KAP di atas diakui sebagai 100. Hal ini mengindikasikan bahwa kolektibilitas debitur pada PT. Bank Mestika Dharma, Tbk secara dominan ada dalam kategori lancar karena aset produktif yang diklasifikasikan berjumlah sedikit.

Berdasarkan hasil perhitungan rasio Penyisihan Penghapusan Aset Produktif (PPAP) pada periode kuartal kedua 2011 sampai dengan kuartal ketiga 2012, menunjukkan rasio PPAP yang dicapai oleh PT. Bank Mestika Dharma, Tbk dikategorikan dalam kelompok Sehat karena rasio PPAP pada periode tersebut masih cukup besar, dengan nilai kredit rasio hampir mencapai nilai kredit rasio maksimum. Sedangkan pada periode kuartal keempat 2012 sampai dengan kuartal kedua 2013, rasio PPAP mengalami penurunan yang mempengaruhi nilai kreditnya sehingga predikat untuk PPAP pada periode ini dikategorikan Cukup Sehat. Hal ini dikarenakan jumlah aktiva produktif yang diklasifikasikan berkurang sehingga penyisihan penghapusan aktiva produktif juga semakin kecil.

\section{c. Management (Kualitas Manajemen)}

Penilaian terhadap faktor manajemen dilakukan secara kuantitatif dengan menggunakan rasio NPM (Net Profit Margin). Adapun perhitungan rasio NPM untuk periode kuartal kedua 2011 sampai dengan kuartal kedua 2013 menunjukkan rasio NPM yang dicapai PT. Bank Mestika Dharma, Tbk dikategorikan dalam kelompok Sehat, dengan rata rata nilai kredit rasio sebesar 75,74, di mana hampir mencapai nilai kredit rasio maksimum. Dengan penggunaan rasio NPM untuk menilai aspek manajemen, hal ini mengindikasikan bahwa tingkat efektifitas yang dapat dicapai oleh usaha operasional PT. Bank Mestika Dharma, Tbk terkait dengan hasil 
akhir dari berbagai kebijaksanaan dan keputusan yang telah dilaksanakan serta kemampuan manajemen dalam mengelola sumber dan penggunaan alokasi dana selama periode berjalan adalah baik dan efisien.

\section{d. Earnings (Kemampuan Menghasilkan Laba)}

Penilaian terhadap earnings dihitung dengan menggunakan rasio Return On Assets (ROA) dan rasio Beban Operasional terhadap Pendapatan Operasional (BOPO). Adapun perhitungan rasio ROA dan BOPO untuk periode kuartal kedua 2011 sampai dengan kuartal kedua 2013 menunjukkan rasio ROA yang dicapai PT. Bank Mestika Dharma, Tbk dikategorikan dalam kelompok Sehat. Meskipun mengalami fluktuasi di setiap periodenya, namun nilai kredit rasio ROA masih baik dan berada di atas nilai kredit maksimum, dengan rata - rata nilai kredit rasio ROA adalah sebesar 360,79. Oleh karena nilai kredit rasio dibatasi maksimum 100 maka nilai kredit rasio ROA di atas diakui sebagai 100. Hal ini mengindikasikan bahwa kemampuan PT. Bank Mestika Dharma, Tbk dalam menghasilkan laba sangat baik.

Berdasarkan hasil perhitungan rasio Beban Operasional terhadap Pendapatan Operasional (BOPO) pada periode kuartal kedua 2011 sampai dengan kuartal kedua 2013, menunjukkan rasio BOPO yang dicapai PT. Bank Mestika Dharma, Tbk dikategorikan dalam kelompok SEHAT, dengan rata - rata nilai kredit rasio adalah sebesar 583,74. Oleh karena nilai kredit rasio dibatasi maksimum 100 maka nilai kredit rasio BOPO di atas diakui sebagai 100. Hal ini menunjukkan efisiensi PT. Bank Mestika Dharma, Tbk dalam meminimalisir biaya operasionalnya sehingga biaya yang dikeluarkan lebih kecil dibandingkan dengan pendapatan yang diterima.

\section{e. Liquidity (Kemampuan Menjamin)}

Penilaian terhadap liquidity dihitung dengan menggunakan Liquid Assets to Current Liability Ratio (LACLR) atau disebut juga dengan Cash Ratio (CR) dan Loan to Deposit Ratio (LDR). Adapun perhitungan rasio $\mathrm{CR}$ dan LDR untuk periode kuartal kedua 2011 sampai dengan kuartal kedua 2013 menunjukkan Cash Ratio yang dicapai PT. Bank Mestika Dharma, Tbk dikategorikan dalam kelompok Sehat, dengan rata - rata nilai kredit rasio adalah sebesar 335,20. Meskipun terjadi fluktuasi dan penurunan nilai rasio yang cukup besar, nilai kredit rasio $\mathrm{CR}$ masih berada di atas batas maksimum yang telah ditetapkan. Oleh karena nilai kredit rasio dibatasi maksimum 100 maka nilai kredit rasio CR di atas diakui sebagai 100. Hal ini menunjukkan bahwa jumlah alat likuid yang dimiliki PT. Bank Mestika Dharma, Tbk lebih besar dan mampu meng-cover kewajiban lancar yang berasal dari dana yang dihimpun dari pihak ketiga.

Berdasarkan perhitungan dapat dilihat bahwa rasio Loan to Deposit Ratio (LDR) yang telah dicapai PT. Bank Mestika Dharma, Tbk pada periode kuartal kedua 2011 sampai dengan kuartal ketiga 2012, dikategorikan dalam kelompok Sehat, di mana rasio LDR pada periode tersebut tidak melebihi batas maksimum yang telah ditetapkan oleh Bank Indonesia. Sedangkan pada periode kuartal keempat 2012, rasio LDR mengalami kenaikan dan terus berlanjut secara signifikan sampai dengan periode kuartal kedua 2013. Hal ini disebabkan karena banyaknya pinjaman yang disalurkan kepada masyarakat namun tidak sebanding dengan kenaikan penghimpunan dana dari pihak ketiga dalam bentuk simpanan, sehingga predikat Loan to Deposit Ratio pada kuartal kedua 2012 adalah Cukup Sehat dan pada kuartal pertama 2013 berada di predikat Kurang Sehat, kemudian berlanjut menjadi Tidak Sehat pada kuartal kedua 2013.

\section{Evaluasi a. Capital \\ Menurut matriks penetapan peringkat} komponen dalam Lampiran 2 Surat Edaran Bank Indonesia Nomor 6/23/DPNP tanggal 21 Mei 2004, bahwa rasio kewajiban penyediaan modal minimum (KPMM) atau rasio CAR yang lebih tinggi sangat signifikan dibandingkan dengan rasio KPMM yang ditetapkan dalam ketentuan, berada pada peringkat komposit 1 (PK-1) sehingga diberi peringkat SEHAT. Sementara itu, hasil perhitungan rasio Capital Adequacy Ratio (CAR) pada periode kuartal kedua 2011 sampai dengan kuartal kedua 2013, pencapaian nilai kredit rasio CAR pada PT. Bank Mestika Dharma, Tbk melampaui batas maksimum ketetapan Bank Indonesia dengan nilai yang sangat signifikan. Hal ini menunjukkan bahwa PT. Bank Mestika Dharma, Tbk mampu menyediakan modal yang cukup besar lebih dari kewajiban penyediaan modal minimum yang telah ditetapkan.

\section{b. Assets}

Aspek Assets diukur dengan menggunakan 2 rasio, yaitu rasio Kualitas Aset Produktif (KAP) dan rasio Penyisihan Penghapusan Aset Produktif (PPAP). Menurut matriks penetapan peringkat komponen dalam Lampiran 2 Surat Edaran Bank Indonesia Nomor 6/23/DPNP tanggal 21 Mei 2004, bahwa aspek assets yang sehat yang diukur dengan rasio KAP harus berada pada peringkat komposit 1 (PK-1) dengan kriteria rasio sangat rendah atau sangat tidak signifikan maupun pada peringkat komposit 2 (PK-2) dengan kriteria rasio rendah atau tidak signifikan. Sementara itu, hasil perhitungan nilai rasio Kualitas Aset Produktif (KAP) yang diperoleh pada periode kuartal kedua 2011 sampai dengan kuartal kedua 2013 adalah rata - rata sebesar 2,95, di mana nilai rasio tersebut rendah atau tidak signifikan. Oleh karena itu, rasio KAP PT. Bank Mestika Dharma, Tbk berada pada peringkat komposit 2 (PK-2) dengan predikat Sehat.

Adapun untuk rasio Penyisihan Penghapusan Aset Produktif (PPAP), menurut matriks penetapan peringkat komponen dalam Lampiran 2 Surat Edaran Bank Indonesia Nomor 6/23/DPNP tanggal 21 Mei 2004, bahwa aspek assets yang sehat yang 
diukur dengan rasio PPAP harus berada pada peringkat komposit 1 (PK-1) dengan kriteria PPAP yang dibentuk secara signifikan lebih tinggi dari PPAP yang wajib dibentuk. Predikat sehat untuk komponen ini juga diberikan apabila rasio PPAP berada di peringkat komposit 2 (PK-2) dengan kriteria PPAP yang dibentuk lebih tinggi dari PPAP yang wajib dibentuk.

Hasil perhitungan nilai kredit rasio PPAP selama periode kuartal kedua tahun 2011 sampai dengan kuartal kedua tahun 2013 secara rata - rata adalah sebesar 85,29 yang menunjukkan bahwa PPAP yang dibentuk lebih tinggi dari PPAP yang wajib dibentuk. Dengan demikian, untuk aspek assets yang diukur dengan rasio PPAP, PT. Bank Mestika Dharma, Tbk berada pada peringkat komposit 2 (PK-2) dengan predikat Sehat.

\section{c. Management}

Penilaian terhadap faktor manajemen dilakukan secara kuantitatif, diproksikan dengan menggunakan rasio NPM (Net Profit Margin). Menurut Sari (2006:31), dengan adanya penggunaan proksi ini maka nilai kredit untuk predikat bank yang sehat berada pada range 64,8 - 80 . Berdasarkan hasil perhitungan rasio Net Profit Margin (NPM) pada periode kuartal kedua 2011 sampai dengan kuartal kedua 2013, rata - rata nilai kredit rasio NPM yang dicapai PT. Bank Mestika Dharma, Tbk adalah 75,74. Oleh karena itu, rasio NPM pada PT. Bank Mestika Dharma, Tbk dikategorikan dalam kelompok Sehat.

\section{d. Earnings}

Aspek Earnings diukur dengan menggunakan 2 rasio, yaitu rasio Return On Assets (ROA) dan rasio Beban Operasional terhadap Pendapatan Operasional (BOPO). Menurut matriks penetapan peringkat komponen dalam Lampiran 2 Surat Edaran Bank Indonesia Nomor 6/23/DPNP tanggal 21 Mei 2004, bahwa aspek earnings yang sehat yang diukur dengan rasio ROA harus berada pada peringkat komposit 1 (PK-1) dengan kriteria perolehan laba sangat tinggi, maupun pada peringkat komposit 2 (PK-2) dengan kriteria perolehan laba tinggi. Secara pro rata, hasil perhitungan nilai kredit rasio ROA yang diperoleh pada periode kuartal kedua 2011 sampai dengan kuartal kedua 2013 adalah rata - rata sebesar 360,79. Hal ini tetap menunjukkan bahwa perolehan laba PT. Bank Mestika Dharma, Tbk dinilai sangat tinggi sehingga rasio ROA berada pada peringkat komposit 1 (PK-1) dengan predikat Sehat. Adapun untuk rasio Beban Operasional terhadap Pendapatan Operasional (BOPO), menurut matriks penetapan peringkat komponen dalam Lampiran 2 Surat Edaran Bank Indonesia Nomor 6/23/DPNP tanggal 21 Mei 2004, bahwa aspek earnings yang sehat yang diukur dengan rasio BOPO harus berada pada peringkat komposit 1 (PK-1) dengan kriteria tingkat efisiensi sangat baik, maupun pada peringkat komposit 2 (PK-2) dengan kriteria tingkat efisiensi baik. Hasil perhitungan nilai kredit rasio BOPO yang diperoleh selama periode kuartal kedua tahun 2011 sampai dengan kuartal kedua tahun 2013 secara rata - rata adalah sebesar 583,74 yang menunjukkan bahwa tingkat efisiensi sangat tinggi karena melampaui batas maksimum nilai kredit rasio. Dengan demikian, untuk aspek earnings yang diukur dengan rasio BOPO, PT. Bank Mestika Dharma, Tbk berada pada peringkat komposit 1 (PK-1) dengan predikat Sehat.

\section{e. Liquidity}

Aspek Liquidity diukur dengan menggunakan 2 rasio, yaitu rasio Cash Ratio (CR) dan rasio Loan to Deposits Ratio (LDR). Menurut matriks penetapan peringkat komponen dalam Lampiran 2 Surat Edaran Bank Indonesia Nomor 6/23/DPNP tanggal 21 Mei 2004, bahwa aspek liquidity yang sehat yang diukur dengan rasio $\mathrm{CR}$ harus berada pada peringkat komposit 1 (PK-1) dengan kriteria sangat likuid atau peringkat komposit 2 (PK-2) dengan kriteria likuid. Secara pro rata, hasil perhitungan nilai kredit rasio $\mathrm{CR}$ yang diperoleh pada periode kuartal kedua 2011 sampai dengan kuartal kedua 2013 adalah rata - rata sebesar 335,20. Meskipun mengalami fluktuasi dan penurunan yang cukup besar, nilai kredit rasio berada jauh di atas batas maksimum nilai kredit rasio yang ditetapkan, yang menunjukkan bahwa rasio CR PT. Bank Mestika Dharma, Tbk dinilai sangat likuid sehingga rasio CR berada pada peringkat komposit 1 (PK-1) dengan predikat Sehat.

Adapun untuk rasio Loan to Deposits Ratio (LDR), menurut matriks penetapan peringkat komponen dalam Lampiran 2 Surat Edaran Bank Indonesia Nomor 6/23/DPNP tanggal 21 Mei 2004, bahwa aspek liquidity yang sehat yang diukur dengan rasio BOPO harus berada pada peringkat komposit 1 (PK-1) dengan kriteria rasio adalah sebesar $50<$ Rasio $\leq 75 \%$, atau peringkat komposit 2 (PK-2) dengan kriteria rasio sebesar 75\% < Rasio $\leq 85 \%$. Hasil perhitungan nilai rasio LDR yang diperoleh selama periode kuartal kedua tahun 2011 sampai dengan kuartal kedua tahun 2013 semakin lama semakin tinggi hingga mencapai batas maksimum rasio LDR yang ditetapkan sehingga menyandang predikat tidak sehat pada kuartal kedua tahun 2013. Jika dihitung secara rata - rata, nilai rasio LDR yang dicapai adalah sebesar 91,90\%, sehingga rasio LDR tidak memenuhi kriteria pada peringkat komposit 1 (PK-1) maupun peringkat komposit 2 (PK-2). Rasio LDR berada pada peringkat komposit 3 (PK-3), di mana kriteria rasio untuk peringkat komposit 3 (PK-3) adalah 85\% < Rasio $\leq 100 \%$. Dengan demikian, untuk aspek liquidity yang diukur dengan rasio LDR, PT. Bank Mestika Dharma, Tbk berada pada peringkat komposit 3 (PK-3) dengan predikat Cukup Sehat. 


\section{KESIMPULAN DAN SARAN}

1. Kesimpulan

Jumlah nilai bersih rasio CAMEL PT. Bank

Mestika Dharma, Tbk pada periode kuartal kedua 2011 sampai dengan kuartal kedua 2013, masihberada di range nilai kredit 81 - 100 sehingga tingkat kesehatan PT. Bank Mestika Dharma, Tbk digolongkan dalam predikat Sehat meskipun nilai bersih rasio CAMEL mengalami fluktuasi serta penurunan yang cukup berarti pada periode kuartal keempat 2012 sampai dengan kuartal kedua 2013.

\section{Saran}

Persentase rasio Penyisihan Penghapusan Aset Produktif (PPAP) juga perlu diperhatikan. Meskipun rasio KAP berada pada predikat sehat, ada baiknya jika cadangan untuk PPAP juga harus tetap dijaga untuk mencegah apabila terjadi resiko kolektibilitas debitur dari lancar menjadi dalam perhatian khusus, kurang lancar, diragukan, ataupun macet. Rasio yang benar - benar menjadi pusat perhatian untuk saat ini adalah rasio Loan to Deposit Ratio (LDR), di mana pada periode kuartal kedua 2013 rasio tersebut telah berada dalam predikat tidak sehat. Hal ini harus segera dibenahi dengan berbagai cara, seperti dengan mengurangi penerimaan pengajuan proposal kredit atau dengan meningkatkan dana pihak ketiga (simpanan) agar posisinya dapat mengimbangi pinjaman yang disalurkan. Peningkatan dana pihak ketiga dapat dilakukan dengan beberapa alternatif, seperti dengan meningkatkan promosi produk simpanan, melakukan refresh terhadap produk simpanan yang telah ada, menambah produk simpanan baru yang lebih inovatif dan mampu bersaing di pasar, meningkatkan kualitas SDM funding marketing agar produk yang telah disediakan dapat dipasarkan dengan baik, dan meningkatkan kualitas pelayanan serta menawarkan berbagai fasilitas yang dapat menarik nasabah untuk menempatkan dana mereka di bank.

\section{E. DAFTAR PUSTAKA}

Amalia, Suhaidah, 2012, Skripsi Analisis Kinerja Keuangan Dengan Menggunakan Metode CAMEL (Studi Kasus Pada PT. Bank Bukopin Tbk. Tahun 2009-2011), Universitas Hasanuddin Makassar.
Bank Indonesia, 1998, UU No. 10 tahun 1998 tentang perubahan terhadap UU No. 7 tahun 1992, Jakarta.

2004, Peraturan Bank Indonesia Nomor 6/10/PBI/2004 tanggal 12 April 2004 perihal Sistem Penilaian Tingkat Kesehatan Bank Umum, Jakarta.

2004, Surat Edaran Bank Indonesia Nomor 6/23/DPNP tanggal 31 Mei 2004 perihal Tatacara Penilaian Kesehatan Bank Umum, Jakarta.

2004, Lampiran 2 Surat Edaran Bank Indonesia Nomor 6/23/DPNP tanggal 31 Mei 2004 - Matriks Kriteria Penetapan Peringkat Komponen, Jakarta.

Dendawijaya, Lukman, 2009, Manajemen Perbankan, Jakarta: Ghalia Indonesia.

Ikatan Akuntan Indonesia, 2009, PSAK No.1 Revisi 2009 Penyajian Laporan Keuangan, Jakarta.

........ 2010, PSAK No.3 Revisi 2010 tentang Laporan Keuangan Interim, Jakarta.

Kasmir, 2011, Manajemen Perbankan, Edisi Revisi Cetakan ke-10, Jakarta: PT. Raja Grafindo Persada.

Kuncoro, Mudrajad, 2003, Metode Riset untuk Bisnis dan Ekonomi, Jakarta: Erlangga.

Sari, Marlupi Nanda Permata, 2006, Skripsi Analisis Kinerja Perbankan Dengan Menggunakan Metode CAMEL (Studi Pada Bursa Efek Jakarta Periode 2002 - 2004), Universitas Brawijaya Malang.

Sudirman, I Wayan, 2013, Manajemen Perbankan: Menuju Bankir Konvensional yang Profesional, Jakarta: Kencana Prenada Media Group.

Sugiyono, 2007, Metode Penelitian Kuantitatif, Kualitatif dan R\&D, Bandung: Alfabeta.

Supranto, J, 2002, Metode Riset Aplikasinya dalam Pemasaran, Jakarta: Rineka Cipta.

Susilo, Y. Sri, dkk, 2000, Bank dan Lembaga Keuangan Lain, Jakarta: Salemba Empat.

Umar, Husein, 2011, Metode Penelitian untuk Skripsi dan Tesis Bisnis, 2011, Jakarta: Rajawali Pers.

www.bankmestika.co.id/index.php?operation=report s: tahun akses 2013 . 